\title{
Elements in Gonad of the Sea Urchin Strongylocentrotus nudus
}

\author{
Taishi Ueda, ${ }^{* 1,2}$ Toshiaki Ishii, ${ }^{* 1}$ Motokazu Nakahara, ${ }^{* 1}$ \\ Ryoichi Nakamura, ${ }^{* 1}$ Yuzuru Suzuki, ${ }^{* 1}$ \\ and Chiaki Shimizu*3 \\ (Received November 19, 1990)
}

\begin{abstract}
As one of serial studies on the variation of elemental concentrations in marine organisms, major elements ( $\mathrm{Ca}, \mathrm{K}, \mathrm{Mg}, \mathrm{Na}, \mathrm{P}$ ) and trace elements (Al, Cd, Co, Cr, Cu, Fe, Mn, Ni, Sr and $\mathrm{Zn}$ ) in 263 specimens of gonad of the sea urchin Strongylocentrotus nudus were determined by inductively coupled plasma atomic emission spectrometry.

The differences of the elemental concentrations in gonad were not significant among three sampling years of 1984, 1985 and 1986, although annual differences of gonad indexes were observed. Seasonal variation in the elemental concentrations was observed on magnesium, sodium, phosphorus and zinc. Furthermore, magnesium, phosphorus and zinc indicated clear differences by sex. For example, the concentration of zinc in ovary was several times higher than that in testis. On the contrary, the concentrations of magnesium and phosphorus in testis were higher than those in ovary.
\end{abstract}

It is well known that elemental concentrations in marine organisms are affected by biological and environmental factors., ${ }^{1,2}$ The relationship between elemental concentrations and influencing factors has been examined for many species of marine organisms. ${ }^{3-8)}$ However, hitherto, little information was reported on the relationship for sea urchin, which is regarded as one of important sea foods in Japan.

In order to clarify the annual, seasonal and sexual variation of elemental concentrations, fifteen elements ( $\mathrm{Al}, \mathrm{Ca}, \mathrm{Cd}, \mathrm{Co}, \mathrm{Cr}, \mathrm{Cu}, \mathrm{Fe}, \mathrm{K}$, $\mathrm{Mg}, \mathrm{Mn}, \mathrm{Na}, \mathrm{Ni}, \mathrm{P}, \mathrm{Sr}$ and $\mathrm{Zn}$ ) in 263 specimens of gonad of Strongylocentrotus nudus were determined by inductively coupled plasma atomic emission spectrometry.

\section{Material and Methods}

\section{Material}

Sea urchin Strongylocentrotus nudus were collected off the coast of Nakaminato City, the Pacific coast of mid Japan, from June 1984 to September 1986.

The body weight and shell diameter of 263 in- dividuals of sea urchins used for analysis were in the range of $43.8-187.7 \mathrm{~g}$ and $46-78 \mathrm{~mm}$, respectively.

Then gonad was taken out and sex was checked with a microscope magnifying 50 times. The sex of specimens in February was histologically determined because of therse being no movement of sperm under microscope in this season. The wet weight of specimens ranged from 3.7 to $28.4 \mathrm{~g}$ depending on season. Twenty specimens collected at each sampling time were dried at $110^{\circ} \mathrm{C}$ for 24 hours and ashed in an electric muffle furnace at $450^{\circ} \mathrm{C}$ for 48 hours.

\section{Measurement of the Elemental Concentrations}

Ashed sample was dissolved in $0.5 \mathrm{~N} \mathrm{\textrm {HNO } _ { 3 }}$ solution, and then filled up to $50 \mathrm{~m} /$ after filtration with a filter paper (Toyo No. 5C). The elemental concentrations in the solution were determined with an inductively coupled plasma atomic emission spectrometer (Shimadzu ICPQ$1012 \mathrm{~W}$ ). The applicability of inductively coupled plasma atomic emission spectrometry to multielement analysis of marine organisms was previously examined by us. $\left.{ }^{\theta} \cdot 10\right)$

*1 Division of Marine Radioecology, National Institute of Radiological Sciences, Isozaki, Nakaminato, Ibaraki 311-12, Japan (上田泰司，石井紀明，中原元相，中村良一。鈴术 讓：放射線医学総合研究所 海洋放射生憼学研究部).

*2 Present address: Marine Ecology Research Institute, Uchi-Kanda, Chiyodaku, Tokyo, Japan 101 (海洋生物璄境研究所).

*8 Faculty of Agriculture, Tokyo University, Yayoi, Bunkyo, Tokyo 113, Japan（消水千秋：東京大学 费学部). 


\section{Results and Discussion}

Difference of Gonad Indexes among Sea Urchins Collected from Three Sampling Stations

The representability of samples of sea urchins in the sampling stations was checked. Sea urchins were collected from three neighboring sampling stations (A, B, and C) in August 1985 and gonad indexes (weight ratio of gonad to whole body) were calculated (see Table 1). Average gonad index of testis from three sampling stations was $14.7 \pm 6.3$ and that of ovary was $18.1 \pm 6.7$. Differences in gonad indexes were not significant between sea urchin from three sampling stations.
Difference of Gonad Indexes among Three Sampling Years

The change of gonad indexes of sea urchins from June 1984 to September 1986 is illustrated in Fig. 1, with seawater temperature of the

Table 2. The comparison of gonad index $(\%)$ for three sampling years

\begin{tabular}{lccc}
\hline Gonad & $\begin{array}{c}1984 \\
(\mathrm{~N}=76)\end{array}$ & $\begin{array}{c}1985 \\
(\mathrm{~N}=107)\end{array}$ & $\begin{array}{c}1986 \\
(\mathrm{~N}=80)\end{array}$ \\
\hline Testis & $17.2 \pm 8.4$ & $11.6 \pm 6.1$ & $13.1 \pm 3.9$ \\
Ovary & $20.6 \pm 13.2$ & $13.2 \pm 4.8$ & $10.2 \pm 3.5$ \\
\hline av \pm sd* $^{*}$ & $19.3 \pm 11.1$ & $12.5 \pm 5.4$ & $11.6 \pm 3.7$ \\
\hline $\begin{array}{l}\text { average and standard deviation for the total number of each } \\
\text { sampling year. }\end{array}$
\end{tabular}

Table 1. The gonad index (weight ratio of gonad to whole body) of S. nudus collected from three sampling stations

\begin{tabular}{clccccc}
\hline $\begin{array}{c}\text { Sampling } \\
\text { station }\end{array}$ & Gonad & $\begin{array}{c}\text { No. of } \\
\text { sample }\end{array}$ & $\begin{array}{c}\text { Shell diameter } \\
(\mathrm{mm})\end{array}$ & $\begin{array}{c}\text { Whole body } \\
\text { weight }(\mathrm{g})\end{array}$ & $\begin{array}{c}\text { Gonad } \\
\text { weight }(\mathrm{g})\end{array}$ & $\begin{array}{c}\text { Gonad } \\
\text { index }(\%)\end{array}$ \\
\hline A & Testis & 8 & $62.0 \pm 6.9$ & $102.1 \pm 29.5$ & $12.9 \pm 4.4$ & $12.6 \pm 4.3$ \\
& Ovary & 12 & $58.2 \pm 4.0$ & $85.7 \pm 16.9$ & $14.8 \pm 4.2$ & $17.3 \pm 4.9$ \\
B & Testis & 9 & $61.0 \pm 9.9$ & $98.3 \pm 37.5$ & $15.6 \pm 7.5$ & $15.9 \pm 7.6$ \\
& Ovary & 11 & $59.8 \pm 7.1$ & $89.7 \pm 26.2$ & $18.4 \pm 7.5$ & $20.5 \pm 8.4$ \\
C & Testis & 10 & $62.9 \pm 5.9$ & $111.2 \pm 29.5$ & $17.3 \pm 7.5$ & $15.6 \pm 6.7$ \\
& Ovary & 10 & $60.7 \pm 6.0$ & $99.1 \pm 24.9$ & $16.4 \pm 6.8$ & $16.5 \pm 6.9$ \\
\hline
\end{tabular}

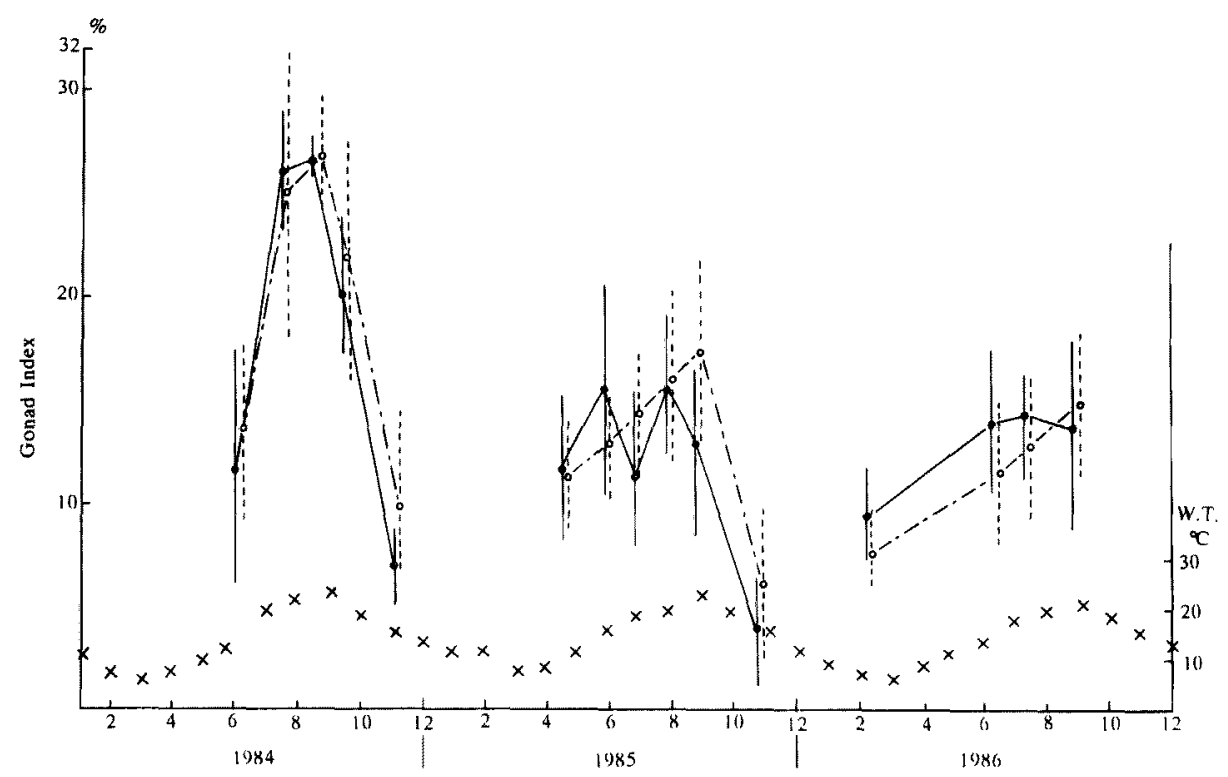

Fig. 1. The variation of gonad indexes of $S$. nudus from June 1984 to September 1986

$\phi:$ averaged value and standard deviation of testis

$\phi$ : averaged value and standard deviation of ovary

$x$ : water temperature (W.T.). 
sampling station monitored by Ibaraki Prefectural Fisheries Station. Although the low gonad index of testis was observed in July 1985, generally gonad indexes increased in spawning season in summer and decreased in autumn corresponding to the falling of the water temperature.

Average gonad indexes for each sampling year are shown in Table 2. The gonad index in 1984 was higher than that in 1985 or in 1986 . From these figures in Table 2, the maximum annual difference of gonad indexes could be considered as being double. High gonad index in 1984 is probably attributable to the abundance of brown algae like Eisenia bicyclis and Undaria pinnatifida as food for sea urchins.

Annual Difference of the Elemental Concentrations

The difference of the elemental concentrations in gonad of sea urchins collected in 1984, 1985 and 1986 is shown in Table 3. Although the difference of gonad indexes among three years was about two times as described above, the average concentrations of each element in gonad of sea urchins were similar among three years, as shown in Table 3.

\section{Seasonal Variation of the Elemental Concentra- tions}

Seasonal variation of the elemental concentrations in gonad was observed on $\mathrm{Mg}, \mathrm{Na}, \mathrm{P}$ and $\mathrm{Zn}$. The concentrations of Mg (Fig. 2, (3)) and $\mathrm{Na}$ (Fig. 2, (4)) in gonad were low in summer and

Table 3. The annual difference of the elemental concentrations $(\mu \mathrm{g} / \mathrm{g}$ wet $w t)$ in gonad of $S$. nudus

\begin{tabular}{lccc}
\hline $\begin{array}{l}\text { Ele- } \\
\text { ment }\end{array}$ & $\begin{array}{c}1984 \\
(\mathrm{~N}=76)\end{array}$ & $\begin{array}{c}1985 \\
(\mathrm{~N}=107)\end{array}$ & $\begin{array}{c}1986 \\
(\mathrm{~N}=80)\end{array}$ \\
\hline $\mathrm{Ca}$ & $390 \pm 190^{*}$ & $330 \pm 430$ & $350 \pm 240$ \\
$\mathrm{~K}$ & $2750 \pm 870$ & $3000 \pm 580$ & $3100 \pm 830$ \\
$\mathrm{Mg}$ & $590 \pm 210$ & $670 \pm 460$ & $710 \pm 190$ \\
$\mathrm{Na}$ & $2600 \pm 860$ & $2850 \pm 1140$ & $2640 \pm 640$ \\
$\mathrm{P}$ & $2170 \pm 790$ & $2470 \pm 650$ & $2480 \pm 780$ \\
\hline $\mathrm{Al}$ & $3.0 \pm 1.7$ & $4.2 \pm 3.8$ & $3.6 \pm 2.6$ \\
$\mathrm{Cd}$ & $0.04 \pm 0.04$ & $0.06 \pm 0.05$ & $0.04 \pm 0.03$ \\
$\mathrm{Co}$ & $0.11 \pm 0.04$ & $0.12 \pm 0.06$ & $0.09 \pm 0.04$ \\
$\mathrm{Cr}$ & $0.14 \pm 0.07$ & $0.18 \pm 0.11$ & $0.14 \pm 0.06$ \\
$\mathrm{Cu}$ & $0.92 \pm 0.55$ & $0.73 \pm 0.24$ & $0.49 \pm 0.15$ \\
$\mathrm{Fe}$ & $9.4 \pm 3.8$ & $11.9 \pm 6.0$ & $9.7 \pm 4.2$ \\
$\mathrm{Mn}$ & $0.22 \pm 0.09$ & $0.25 \pm 0.15$ & $0.24 \pm 0.06$ \\
$\mathrm{Ni}$ & $0.13 \pm 0.07$ & $0.19 \pm 0.14$ & $0.14 \pm 0.06$ \\
$\mathrm{Sr}$ & $3.5 \pm 1.3$ & $4.0 \pm 2.7$ & $3.3 \pm 1.8$ \\
$\mathrm{Zn}$ & $33.7 \pm 23.8$ & $36.4 \pm 31.0$ & $30.9 \pm 22.9$ \\
\hline$*$ average and standard deviation. &
\end{tabular}

rose in autumn. On the contrary, the $\mathrm{P}$ concentration (Fig. 2, (5)) was high in summer and then decreased. Although the $\mathrm{Zn}$ concentration in testis is constant through the year, the $\mathrm{Zn}$ concentration in ovary, shows the highest value in summer, as shown in Fig. 2, (15). Both P and $\mathrm{Zn}$ seem to have a particular role in the maturation of ovary of sea urchins.

There was no seasonal variation in concentrations of other elements, as shown in Fig. 2, (1-2 and 6-14).

Difference of the Elemental Concentrations due to Sex

The differences of the elemental concentrations between testis and ovary were statistically examined. As shown in Table 4, the significant differences were observed on $\mathrm{Mg}, \mathrm{P}$ and $\mathrm{Zn}$. The concentrations of $\mathrm{Mg}$ and $\mathrm{P}$ in testis were higher than those in ovary. Although the $\mathrm{Zn}$ concentration in ovary showed a clear seasonal variation as in Fig. 2, (15), the average value $(54.9 \mu \mathrm{g} / \mathrm{g}$ wet wt) of $\mathrm{Zn}$ in ovary was much higher than that $(7.9 \mu \mathrm{g} / \mathrm{g}$ wet $\mathrm{wt})$ in testis. As to $\mathrm{Ca}, \mathrm{K}, \mathrm{Al}, \mathrm{Cd}$ and $\mathrm{Co}$, there was no difference of the concentrations between testis and ovary, but concerning other ten elements the differences were obscure.

In conclusion, the fluctuation of the elemental concentrations in sea urchins can be generally considered to be less than three times among years or seasons. Furthermore, it is found that

Table 4. The comparison of the elemental concentrations $(\mu \mathrm{g} / \mathrm{g}$ wet $w t)$ between testis and ovary of $S$. nudus

\begin{tabular}{lccl}
$\begin{array}{l}\text { Ele- } \\
\text { ment }\end{array}$ & $\begin{array}{c}\text { Testis } \\
(\mathrm{N}=117)\end{array}$ & $\begin{array}{c}\text { Ovary } \\
(\mathrm{N}=146)\end{array}$ & $\begin{array}{c}\text { Statistical } \\
\text { significance }\end{array}$ \\
\hline $\mathrm{Ca}$ & $320 \pm 210^{*}$ & $370 \pm 180$ & no difference \\
$\mathrm{K}$ & $2800 \pm 640$ & $3100 \pm 720$ & no difference \\
$\mathrm{Mg}$ & $800 \pm 180$ & $510 \pm 100$ & $p<0.001^{* *}$ \\
$\mathrm{Na}$ & $2900 \pm 1100$ & $2600 \pm 810$ & $p<0.01$ \\
$\mathrm{P}$ & $3000 \pm 550$ & $1800 \pm 300$ & $p<0.001$ \\
\hline $\mathrm{Al}$ & $3.6 \pm 2.9$ & $3.8 \pm 4.1$ & no difference \\
$\mathrm{Cd}$ & $0.05 \pm 0.07$ & $0.04 \pm 0.02$ & no difference \\
$\mathrm{Co}$ & $0.10 \pm 0.05$ & $0.11 \pm 0.05$ & no difference \\
$\mathrm{Cr}$ & $0.18 \pm 0.08$ & $0.14 \pm 0.09$ & $p<0.01$ \\
$\mathrm{Cu}$ & $0.64 \pm 0.43$ & $0.80 \pm 0.32$ & $p<0.01$ \\
$\mathrm{Fe}$ & $11.8 \pm 5.9$ & $8.8 \pm 3.9$ & $p<0.01$ \\
$\mathrm{Mn}$ & $0.19 \pm 0.11$ & $0.27 \pm 0.15$ & $p<0.01$ \\
$\mathrm{Ni}$ & $0.17 \pm 0.13$ & $0.14 \pm 0.09$ & $p<0.05$ \\
$\mathrm{Sr}$ & $3.4 \pm 1.4$ & $3.8 \pm 1.4$ & $p<0.05$ \\
$\mathrm{Zn}$ & $7.9 \pm 2.9$ & $54.9 \pm 17.2$ & $p<0.001$ \\
\hline$*$ & average and standard deviation. & \\
${ }^{* *}$ probability. & &
\end{tabular}



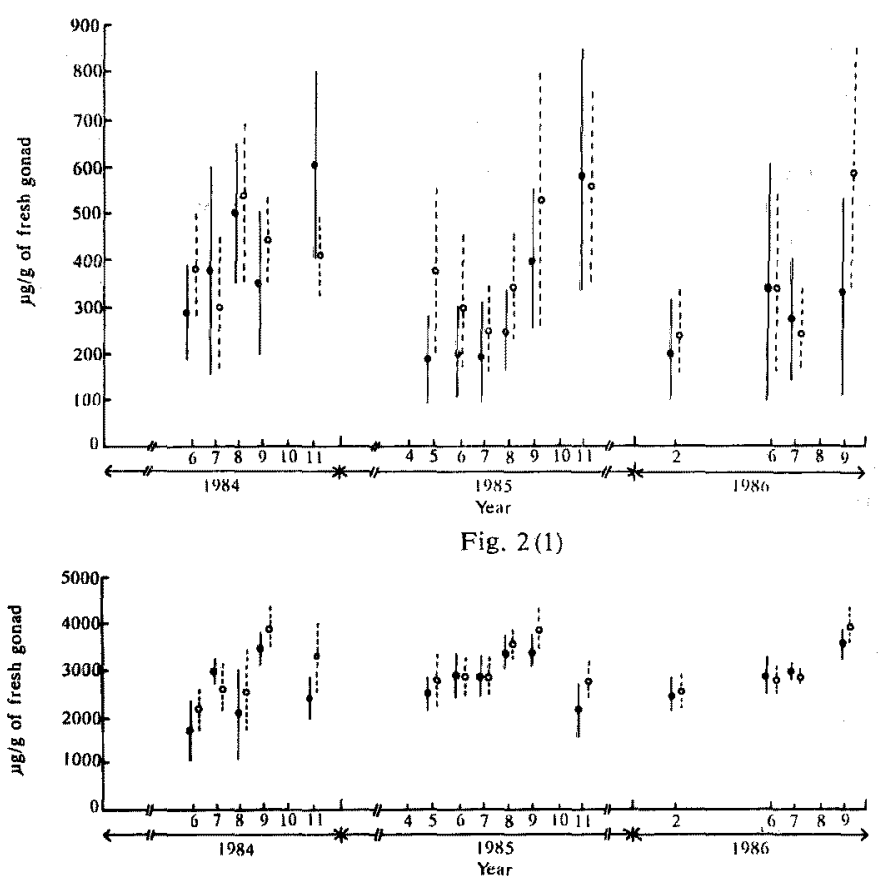

Fig. $2(2)$

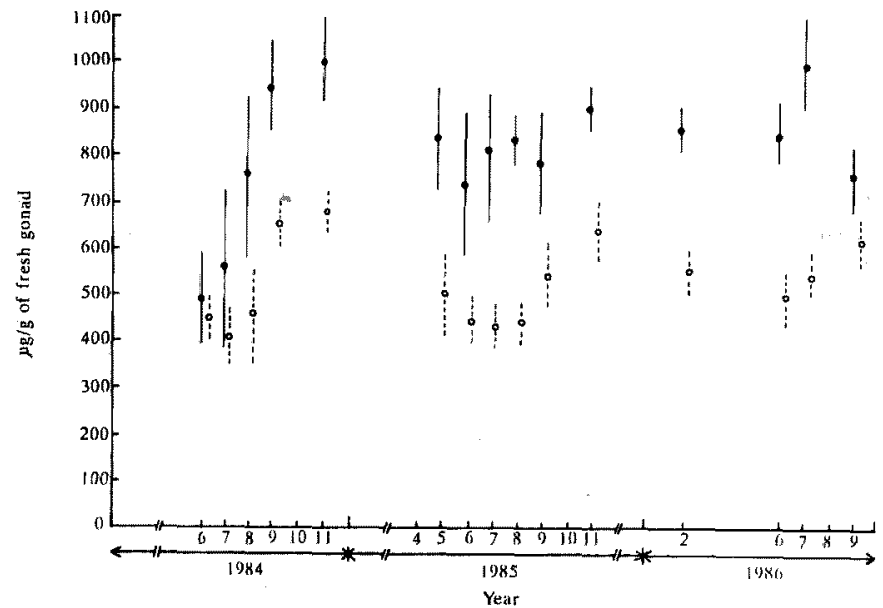

(3) $\mathrm{Mg}$

Fig. 2(3)

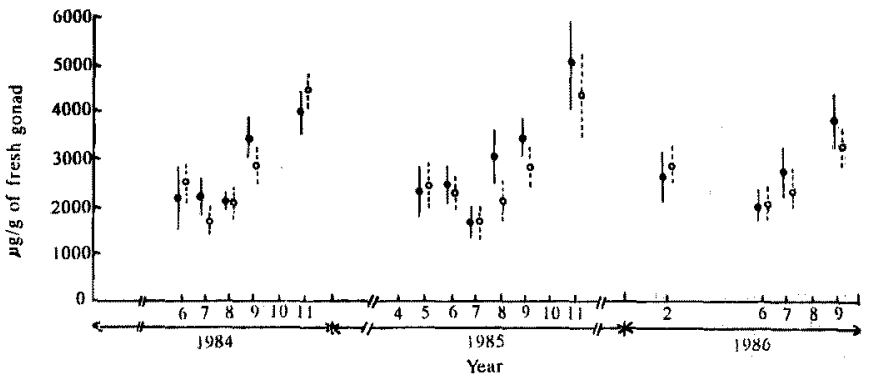

Fig. 2 (4) 
Elements in Gonad of Sea Urchin

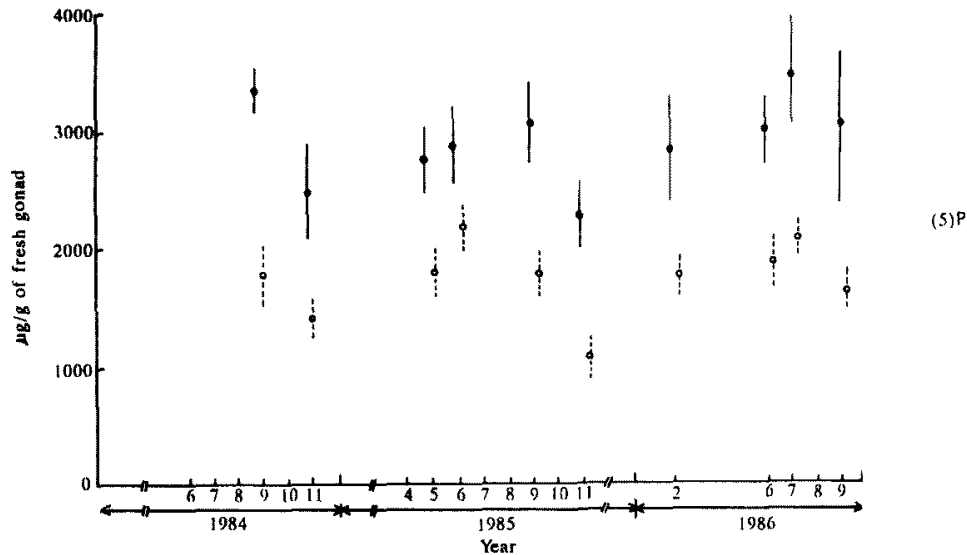

Fig. 2(5)

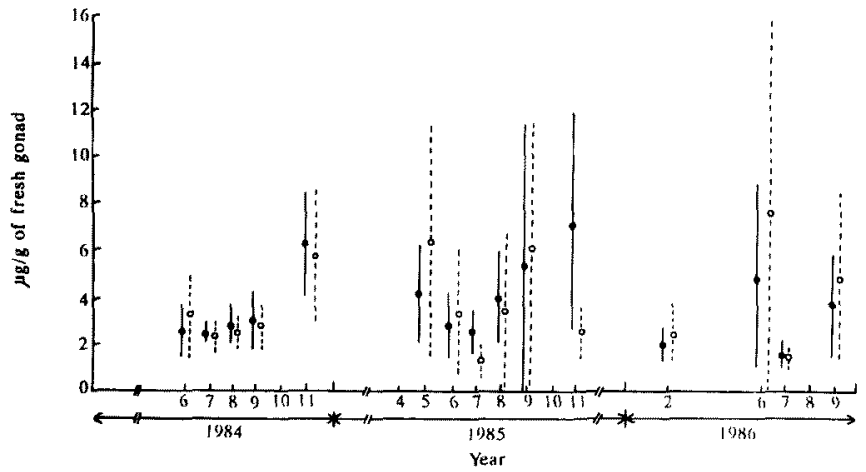

(6)A)

Fig. 2(6)

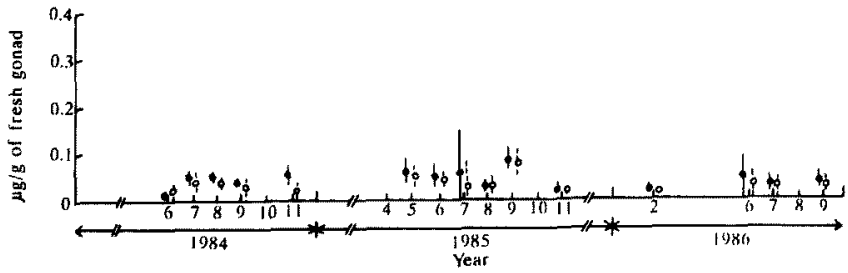

(7) Cd

Fig. 2(7)

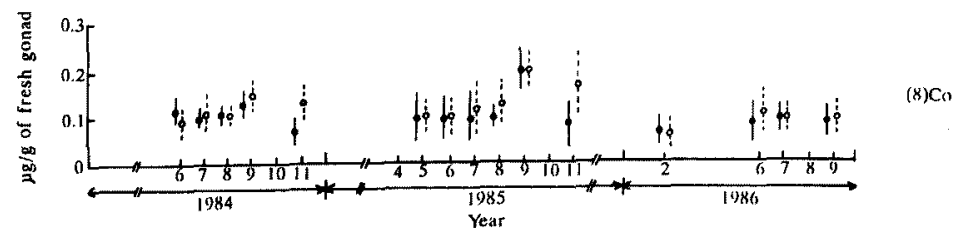

Fig. 2(8) 


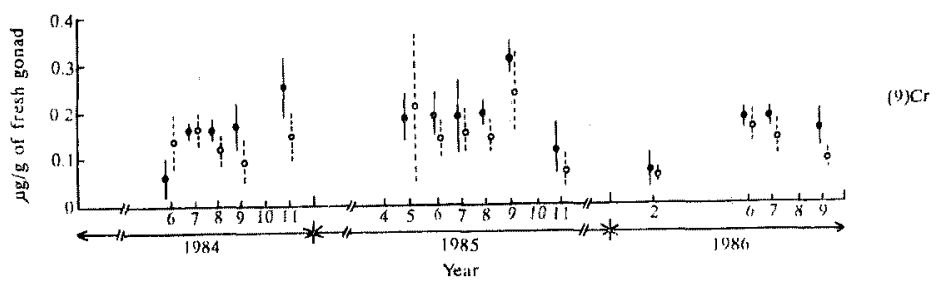

Ffg. 2(9)

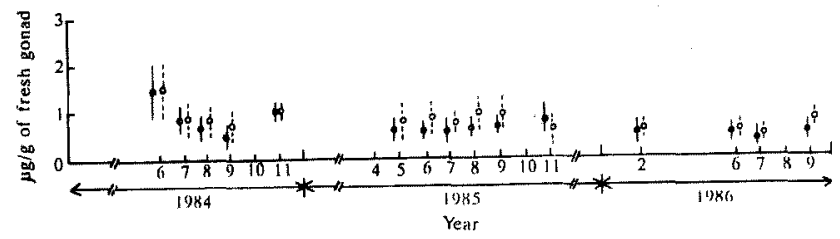

Fig. 2(10)

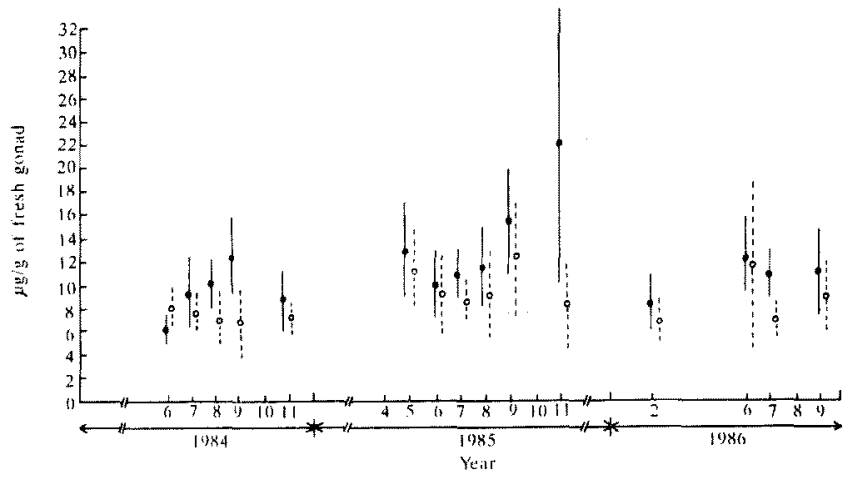

(11) $\mathrm{Fe}$

Fig. $2(11)$

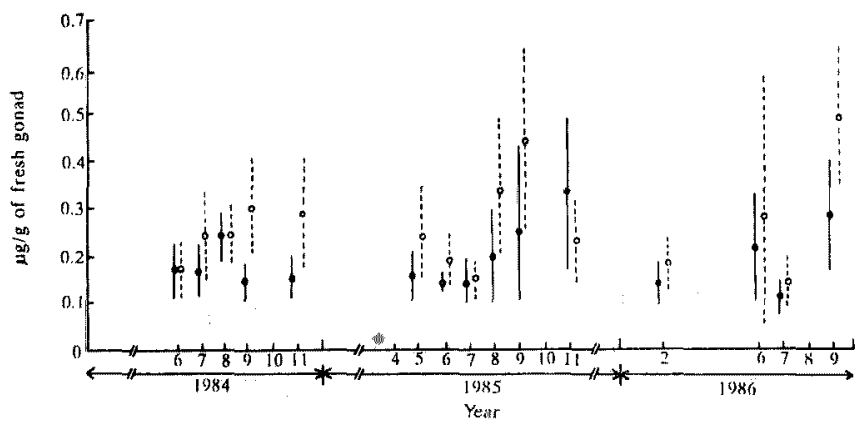

(12) $\mathrm{Mn}$

Fig. 2(12) 


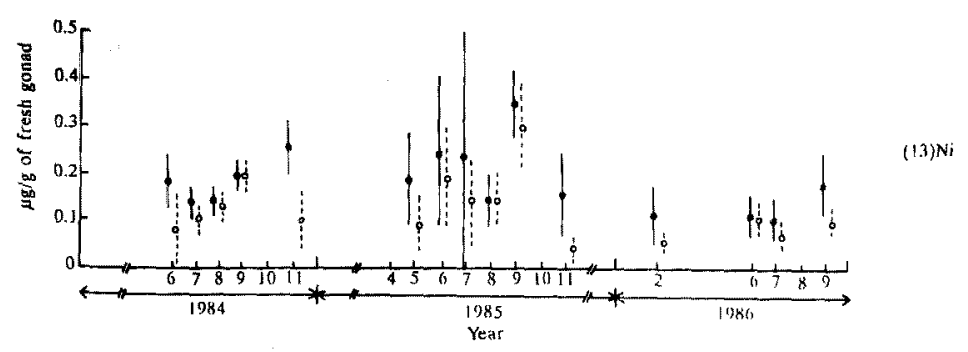

Fig. 2(13)

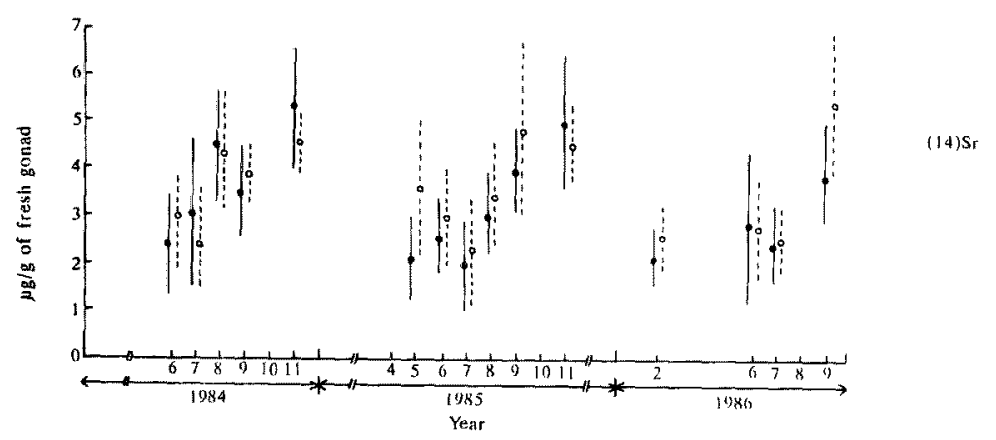

Fig. 2(14)

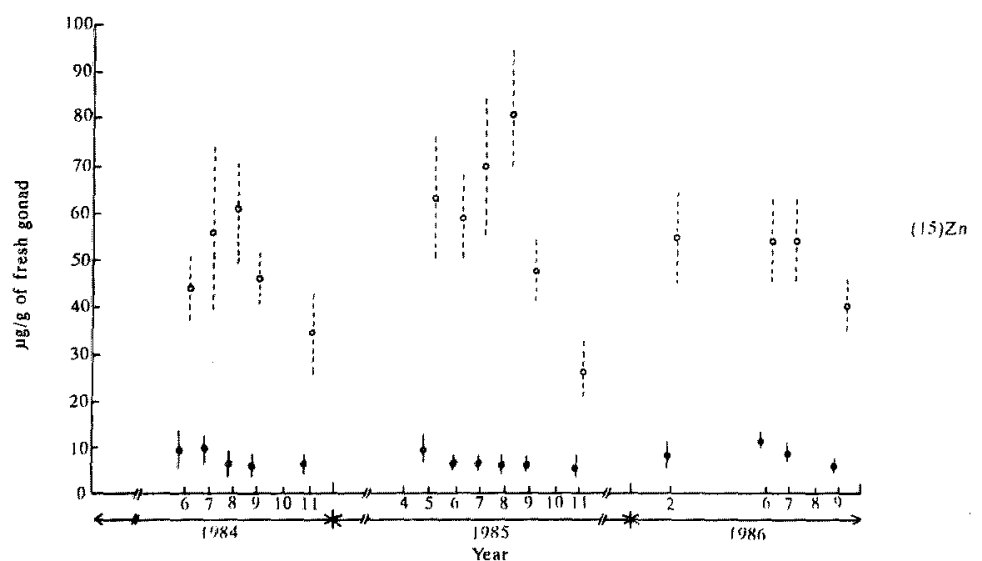

Fig. 2(15)

Fig. 2. (1)-(15) The variation of the elemental concentrations ( $\mu \mathrm{g} / \mathrm{g}$ wet wt) in gonad of $S$. nudus

- : averaged value and standard deviation of testis

$\phi$ : averaged value and standard deviation of ovary.

the differences by sex are not significant except for $\mathrm{Mg}, \mathrm{P}$ and $\mathrm{Zn}$.

The concentration factor is a useful parameter for the internal dose estimation of human beings who consume sea foods contaminated by radionuclides.
In order to obtain the concentration factors, the elemental concentrations other than $\mathrm{Mg}, \mathrm{P}$ and $\mathrm{Zn}$ were averaged on both testis and ovary because of no difference due to sex. In the cases of $\mathrm{Mg}, \mathrm{P}$ and $\mathrm{Zn}$ indicating clear differences by 
Table 5. The elemental concentrations and concentration factors (CF) by gonad of $S$. nudus

\begin{tabular}{|c|c|c|c|}
\hline Element & $\begin{array}{l}\text { Average conc. } \\
\text { in gonad } \\
(\mu \mathrm{g} / \mathrm{g} \text { wet } \mathrm{wt})\end{array}$ & $\begin{array}{l}\text { Conc. in } \\
\text { seawater } \\
(\mu \mathrm{g} / \mathrm{m} l)\end{array}$ & $\mathrm{CF}$ \\
\hline $\mathrm{Ca}$ & 350 & 410 & 0.85 \\
\hline K & 3000 & 391 & 7.7 \\
\hline $\mathrm{Mg}$ (testis) ${ }^{*}$ & 800 & 1290 & 0.62 \\
\hline $\mathrm{Na}$ & 2700 & 10770 & 0.25 \\
\hline$P$ (testis)* $^{*}$ & 3000 & $8.8 \times 10^{-2}$ & $3.4 \times 10^{4}$ \\
\hline $\mathrm{Al}$ & 3.7 & $1.0 \times 10^{-6}$ & $3.7 \times 10^{B}$ \\
\hline $\mathrm{Cd}$ & 0.044 & $1.1 \times 10^{-4}$ & $4.0 \times 10^{2}$ \\
\hline Co & 0.11 & $3 \times 10^{-5}$ & 3. $7 \times 10^{3}$ \\
\hline $\mathrm{Cr}$ & 0.16 & $2 \times 10^{-4}$ & $8.0 \times 10^{2}$ \\
\hline $\mathrm{Cu}$ & 0.72 & $9 \times 10^{-4}$ & $8.1 \times 10^{2}$ \\
\hline $\mathrm{Fe}$ & 10.3 & $3 \times 10^{-3}$ & $3.4 \times 10^{3}$ \\
\hline Mn & 0.23 & $4 \times 10^{-4}$ & $5.8 \times 10^{2}$ \\
\hline $\mathrm{Ni}$ & 0.16 & $6.6 \times 10^{-3}$ & $2.3 \times 10$ \\
\hline $\mathrm{Sr}$ & 3.6 & 8.1 & 0.41 \\
\hline $\operatorname{Zn}($ ovary)* & 54.9 & $5 \times 10^{-8}$ & $1.1 \times 10^{4}$ \\
\hline
\end{tabular}

sex, the concentration factors were calculated using each higher elemental concentration for the conservative estimation of the internal dose of human beings. The elemental concentrations in seawater were cited from the data edited by Turekian. ${ }^{11)}$ The values as seen in Table 5 were in accordance with previous data ${ }^{12}$ except $\mathrm{Cd}$. On the value of $\mathrm{Cd}$, further investigation should be performed.

\section{Acknowledgement}

We are grateful to Ibaraki Prefectural Fisheries Station for the offer of data about seawater tem- perature from 1984 to 1986 . Furthermore, we are thankful to Ms. M. Matsuba and M. Kurosawa for the technical assistance.

\section{References}

1) G. W. Bryan: in "Marine Pollution" (ed. by R. Johnston), Academic Press, London, 1976, pp. 185-290.

2) T. Ishii: in "Environmental Radioactivity" (ed. by M. Saiki), SOFT SCIENCE, Tokyo, 1984, 514-528.

3) E. D. Goldberg, V. T. Bowen, J. W. Farrington, G. Harvey, J. H. Martin, P. L. Parker, R. W. Risebrough, W. Robertoson, E. Schneider, and E. Gamble: Environ. Conserv., 5, 101-125 (1978).

4) R. Fuge and K.H. James: Marine Pollution Bullerin, 5, 9-12 (1974).

5) C. R. Boyden: J. Mar. Biol. Ass. U.K., 57, 675-714 (1977).

6) T. Ishii, M. Kodama, M. Ishikawa, M. Matsuba, M. Kurosawa, and T. Koyanagi: Nippon Suisan Gakkaishi, 53, 1095-1102 (1987).

7) S. Hirano, T. Ishii, R. Nakamura, M. Matsuba, and T. Koyanagi: RADIOISOTOPE, 32, 319322 (1983).

8) R. Nakamura, M. Nakahara, Y. Suzuki, and T. Ueda: Nippon Suisan Gakkaishi, 48, 1639-1644 (1982).

9) T. Ishii, S. Hirano, M. Matsuba, and T. Koyanagi: Nippon Suisan Gakkaishi, 46, 1375-1380 (1980).

10) T. Ishii, R. Nakamura, M. Ishikawa, and T. Koyanagi: Nippon Suisan Gakkaishi, 51, 609-617 (1985).

11) K. K. Turekian: in "Handbook of Geochemistry" (ed. by K. H. Wedepol), Springer-Verlag, Berlin, 1969, pp. 309-311.

12) S. E. Thompson, C. A. Burton, D. J. Quinn, and C. NgYook: UCRL-50564 Rev. 1 (1972). 